\title{
PENGARUH PEMBERIAN INSULIN-LIKE GROWTH FACTOR-I (IGF-I) DARI SERUM KUDA CROSSBREED BUNTING TERHADAP FOLIKULOGENESIS MENCIT (Mus musculus)
}

\section{EFFECT OF INSULIN-LIKE GROWTH FACTOR-I (IGF-I) DERIVED FROM PREGNANT CROSSBREED MARE SERUM IN MICE (Mus musculus) FOLLICULOGENESIS}

\author{
Abdullah $^{1)}$, Tjuk Imam Restiadi ${ }^{2)}$, Nunuk Dyah Retno Lastuti' ${ }^{3)}$, Tita Damayanti ${ }^{4)}$, \\ Wurlina $^{5)}$, Erma Safitri' \\ ${ }^{1)}$ Student, ${ }^{2,4,5,6)}$ Veterinary Reproduction Department ${ }^{3)}$ Veterinary Parasitology Department \\ Faculty of Veterinary Medicine, Airlangga University \\ email: doellahlah@gmail.com
}

\begin{abstract}
The purpose of the research was to know the effect of Insulin-Like Growth Factor-I (IGF-I) derived from pregnant crossbreed mare serum (PMS) in mice (Mus musculus) folliculogenesis. The subject of this research were 20 female mice. The research was arranged by Completely Randomized Design (CRD) with four treatments and five replications. The treatment were $\mathrm{K} 0=$ $10 \mathrm{ng} / \mathrm{ml}$ of physiological $\mathrm{NaCl}, \mathrm{P} 1=10 \mathrm{ng} / \mathrm{ml}$ of IGF-I PMS, P2 $=20 \mathrm{ng} / \mathrm{ml}$ of IGF-I PMS, and P3 $=40 \mathrm{ng} / \mathrm{ml}$ of IGF-I PMS. Observed variables are number of primary, secondary, tertiary and de Graff follicles. During the treatment the estrus cycle was also observed. The data of follicles number were analyzed by Analysis of Variance (ANOVA), followed by HSD (Honestly Significant Difference) test. The result showed that the addition of IGF-I PMS significantly affect $(\mathrm{p}<0,05)$ on increasing of the primary and secondary follicles number. The addition of IGF-I PMS $20 \mathrm{ng} / \mathrm{ml}$ and $40 \mathrm{ng} / \mathrm{ml}$ can increase the primary and secondary follicle significantly $(\mathrm{p}<0,05)$.
\end{abstract}

Key words: IGF-I, IGF-I pregnant crossbreed mare serum, Folliculogenesis, Mus musculus

\section{Pendahuluan}

Kebutuhan manusia akan protein hewani dari tahun ke tahun terus bertambah, tercatat di Indonesia terjadi peningkatan konsumsi daging sebesar $6,65 \%$ dari tahun 2013 hingga 2014 (Direktorat Jenderal Peternakan dan Kesehatan Hewan, 2015) dan diperkirakan setiap tahunnya akan terus bertambah. Menurut data Badan Pusat Statistik setiap tahunnya terjadi penurunan jumlah perusahaan peternakan. Pada tahun 2011 hingga 2014 terjadi penurunan yang signifikan terhadap ternak sapi yang dipotong di RPH (Rumah Potong Hewan). Hal ini membuat kekurangan suplai daging di pasar. Banyak upaya yang telah dilakukan oleh pemerintah untuk megatasi masalah ini, salah satunya dengan impor daging sapi dari Australia namun, ini juga masih belum mengatasi sepenuhnya karena harga daging impor tetap lebih mahal dibandingkan dengan daging lokal dan tidak mungkin terus menerus bergantung pada impor daging saja. Sehingga memunculkan upaya untuk meningkatkan populasi dan produktivitas dari ternak.

Berdasarkan Peraturan Menteri Pertanian (Permentan) no. 48 tahun 2016 tentang Upaya Khusus Percepatan Peningkatan Populasi Sapi dan Kerbau Bunting, Pasal 5 ayat 1 dan 2 , upaya khusus percepatan peningkatan populasi sapi dan kerbau bunting dilakukan melalui sistem manajemen reproduksi. Sistem manajemen reproduksi meliputi pemeriksaan status reproduksi dan gangguan reproduksi, pelayanan Inseminasi Buatan (IB) dan kawin alam, pemenuhan semen beku dan $\mathrm{N}_{2}$ cair, pengendalian betina produktif, dan pemenuhan hijauan pakan ternak dan konsentrat. Upaya untuk meningkatkan populasi dan produktivitas ternak ini, peternak sering mengalami kendala terutama masalah reproduksi. Masalah reproduksi yang biasa terjadi pada sapi induk antara lain, ternak bunting tetapi tidak menunjukkan tanda 
berahi, kelainan hormon reproduksi (progesteron tinggi) sehingga menyebabkan terjadinya bunting semu dan kista luteal, keluarnya leleran berwarna putih, kekuningan atau kehijauan yang berbau tidak sedap karena peradangan pada saluran reproduksi, tanda berahi yang tidak teramati peternak, kekurangan pakan sehingga menyebabkan hipofungsi ovarium, kawin berulang, dan kelainan hormon reproduksi (estrogen tinggi) yang dapat disebabkan oleh kista folikel (Ulum dan Purwantara, 2015)

Menurut Ismudiono, dkk. (2010) reproduksi atau perkembangbiakan merupakan proses pembentukan individu baru, dalam hal ini melalui proses perkawinan baik alami maupun buatan. Menurut Nursyah (2012) reproduksi adalah proses fisiologis pada seluruh makhluk hidup untuk mempertahankan keturunan dan kelangsungan hidup. Proses ini memerlukan kerja hormon reproduksi yaitu hormon yang secara langsung atau tidak langsung berpartisipasi dalam proses reproduksi. Ovarium merupakan organ reproduksi yang memiliki peran yang sangat penting. Ovarium memiliki dua fungsi dasar yaitu memproduksi oosit yang fertilizable dan memiliki perkembangan yang sempurna, serta untuk mensekresi hormon steroid yang diperlukan untuk mempersiapkan saluran reproduksi dalam proses fertilisasi dan implantasi (Palermo, 2007) sehingga ketika ovarium mengalami gangguan maka dapat mengganggu sistem reproduksi. Banyak penelitian yang menggunakan bahan bioaktif yang bertujuan untuk meningkatkan kemampuan reproduksi.

Salah satu bahan bioaktif yang berperan dalam sistem reproduksi hewan betina adalah Insulin-Like Growth Factor-I (IGFI). Suplementasi IGF-I dalam medium maturasi dan kultur oosit dapat menstimulasi dan meningkatkan jumlah oosit yang matang, meningkatkan hasil in vitro fertilization (IVF) (Oberlender et al., 2013), dan jumlah embrio yang mencapai tahap blastosis pada beberapa jenis ternak termasuk diantaranya babi dan sapi (Neira et al., 2010), serta kerbau (Singhal et al., 2009). Magalhaes-Padilha et al. (2012) melaporkan bahwa penambahan $I G F-I$ selama kultur folikel preantral babi dapat meningkatkan diameter folikel, meningkatkan eks- presi mRNA Insulin-Like Growth Factor Receptor-I (IGFR-I) dengan suplementasi Follicle Stimulating Hormone (FSH) selama kultur dan oosit yang dihasilkan dapat memulai proses meiosis setelah maturasi. Begitu juga menurut Silva et al. (2009) bahwa IGF dapat meningkatkan proliferasi sel-sel granulosa, steroidogenesis dan pertumbuhan oosit pada sebagian besar spesies mamalia. Selain itu penelitian yang dilakukan Echternkamp et al. (1990) memberikan bukti yang menunjukkan bahwa kejadian kembar pada sapi dikaitkan dengan peningkatan konsentrasi IGF-I pada serum maupun cairan folikel. IGF-I dari ovarium dan (atau) yang berasal dari sirkulasi sistemik, memainkan peran dalam regulasi folikulogenesis dan merupakan mediator dari komponen genetik dari beberapa ovulasi pada sapi.

\section{Materi dan Metode Penelitian}

Penelitian ini merupakan penelitian eksperimental laboratorik dengan menggunakan Rancangan Acak Lengkap (RAL). Penelitian ini menggunakan hewan coba mencit betina galur Balb/C umur 28-32 hari yang diperoleh dari Pusat Veterineria Farma, Surabaya dan telah dinyatakan laik etik oleh Komisi Etik Penelitian, Fakultas Kedokteran Hewan, Universitas Airlangga. Mencit yang digunakan sebanyak 20 ekor dimana masing-masing dikelompokkan dalam 4 kelompok perlakuan. Kelompok kontrol (K0) diinjeksi dengan $\mathrm{NaCl}$ fisiologis sebanyak $0,1 \mathrm{ml}$, kelompok perlakuan (P1) diinjeksi dengan $I G F-I$ SKB dosis $10 \mathrm{ng} / \mathrm{ml}$ sebanyak $0,1 \mathrm{ml}$, kelompok perlakuan (P2) diinjeksi dengan $I G F-I$ SKB dosis $20 \mathrm{ng} / \mathrm{ml}$ sebanyak $0,1 \mathrm{ml}$, dan kelompok perlakuan (P3) diinjeksi dengan $I G F-I$ SKB dosis 40 $\mathrm{ng} / \mathrm{ml}$ sebanyak $0,1 \mathrm{ml}$. Semua penyuntikkan dilakukan secara subkutan. Penyuntikan IGF-I SKB dilakukan sebanyak 5 kali dalam kurun waktu 5 hari. Sebelum melakukan penyuntikkan semua mencit dilakukan pengambilan ulas vagina untuk mengetahui status reproduksinya.

\section{Pembedahan Hewan Coba dan Pem- buatan Sediaan Histopatologi Ovarium Mencit}

Pada akhir penelitian hewan coba dikorbankan dengan cara dianatesi dengan eter hingga mati dan kemudian dilakukan 
pembedahan untuk mengambil ovarium kirinya. Setelah diambil, ovarium kiri dipisahkan dari jaringan lemaknya dan dimasukkan dalam formalin $10 \%$ untuk memfiksasi jaringan. Setelah 1-2 hari terfiksasi, ovarium kiri masuk ke tahap selanjutnya untuk pembuatan preparat histopatologi ovarium mencit. Pembuatan preparat histopatologi ovarium mencit dilakukan dengan teknik rutin pewarnaan Haematoxylin-Eosin di Laboratorium Patologi Veteriner, Fakultas Kedokteran Hewan, Universitas Airlangga.

\section{Identifikasi dan Penghitungan Folikel Ovarium Mencit}

Preparat ovarium yang telah jadi diamati dibawah mikroskop dengan perbesaran lensa okuler 10x serta lensa objektif yang bervariasi mulai perbesaran 4x-40x. Klasifikasi folikel didasarkan pada ukuran oosit pada folikel dari masing-masing tahap perkembangan, pada ukuran folikel ditentukan oleh jumlah sel yang menyelimuti folikel, dan morfologi folikel (Pedersen and Peters, 1968). Folikel primer terdiri dari satu lapisan sel granulosa pipih dan kubis atau hanya kubis saja, folikel sekunder terdiri dari dua atau lebih lapisan sel granulosa kubis (Gougeon et al. 1996), folikel antral kecil (folikel tersier) memiliki rongga tersegmentasi dengan dua atau lebih antrum, dan folikel antral besar (folikel de Graff) memiliki satu rongga yang disebut antrum yang terus menerus membesar (Griffin et al. 2006). Penghitungan jenis folikel (baik preantral dan antral) pada ovarium dihitung dengan cara memeriksa seluruh lapang pandang. Kemudian data dikumpulkan dan dianalisis.

\section{Analisis Data}

Data jumlah folikel primer, sekunder, tersier dan de Graff setelah diberi perlakuan IGF-I SKB dianalisa dengan menggunakan Uji ANOVA (Analysis of Variance). Apabila terdapat beda nyata $(\mathrm{p}<0,05)$, maka dilanjutkan dengan Uji Beda Nyata Jujur (BNJ) (Kusningrum, 2011). Adapun analisa dan pengolahan data untuk penelitian ini menggunakan program statistik komputer dengan menggunakan software SPSS 20 (Statistical Product and Service Solution 20).

\section{Hasil dan Pembahasan \\ Hasil Identifikasi dan Penghitungan Jumlah Folikel Ovarium Mencit (Mus musculus) Perlakuan Insulin-like Growth Factor-I (IGF-I) Serum Kuda Crossbreed Bunting}

Hasil penghitungan jumlah folikel primer ovarium mencit setelah diberi Insulinlike Growth Factor-I (IGF-I) Serum Kuda Crossbreed Bunting (SKB) menunjukkan adanya peningkatan jumlah folikel primer pada ovarium mencit (Mus musculus). Pemberian Insulin-like Growth Factor-I (IGF-I) serum kuda crossbreed bunting menunjukkan perbedaan yang nyata $(\mathrm{P}<0,05)$ pada jumlah folikel primer mencit (Mus musculus) pada perlakuan P1, P2, dan P3. Dosis IGF-I SKB $20 \mathrm{ng} / \mathrm{ml}$ dan $40 \mathrm{ng} / \mathrm{ml}$ (P2 dan P3) dapat meningkatkan jumlah folikel primer ovarium mencit (Mus musculus $)(\mathrm{P}<0,05)$.

Hasil penghitungan jumlah folikel sekunder ovarium mencit (Mus musculus) setelah diinjeksi Insulin-like Growth Factor-I (IGF-I) dari serum kuda crossbreed bunting (SKB) menunjukkan adanya perubahan. Pemberian Insulin-like Growth Factor-I (IGF-I) dari serum kuda crossbreed bunting menunjukan perbedaan yang nyata $(\mathrm{P}<0,05)$ terhadap jumlah folikel sekunder ovarium mencit (Mus musculus) pada perlakuan $\mathrm{P} 1, \mathrm{P} 2$, dan $\mathrm{P} 3$. Dosis $I G F-I$ SKB $20 \mathrm{ng} / \mathrm{ml}$ dan $40 \mathrm{ng} / \mathrm{ml}$ (P2 dan P3) dapat meningkatkan jumlah folikel sekunder ovarium mencit (Mus musculus) dibandingkan dengan kelompok kontrol (K0) $(\mathrm{P}<0,05)$. Selain itu, Dosis IGF-I SKB 20 $\mathrm{ng} / \mathrm{ml}$ dan $40 \mathrm{ng} / \mathrm{ml}$ (P2 dan P3) juga berbeda nyata $(\mathrm{P}<0,05)$ dengan kelompok P1 dalam meningkatkan jumlah folikel sekunder ovarium mencit (Mus musculus).

Hasil penghitungan jumlah folikel tersier dan de Graff ovarium mencit (Mus musculus) setelah diinjeksi Insulin-like Growth Factor-I (IGF-I) dari serum kuda crossbreed bunting (SKB) tidak menunjukkan adanya perubahan. Pemberian Insulin-like Growth Factor-I (IGF-I) dari serum kuda crossbreed bunting tidak menunjukan perbedaan yang nyata $(\mathrm{P}>0,05)$ terhadap jumlah folikel tersier dan de Graff ovarium mencit (Mus musculus) pada perlakuan P1, P2, dan P3.

Gambar masing-masing folikel terdapat pada Gambar 1. Data hasil penghitungan 
jumlah folikel primer, sekunder, tersier, dan de Graff ovarium mencit (Mus musculus) setelah diinjeksi IGF-I SKB disajikan dalam Tabel 1, sedangkan grafik jumlah folikel primer, sekunder, tersier dan de Graff ovarium mencit (Mus musculus)

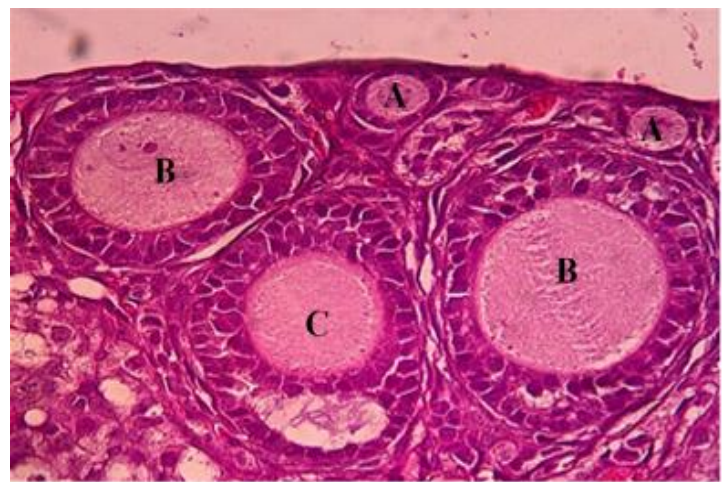

Gambar 1. Hasil identifikasi folikel ovarium mencit (Mus musculus). (A) Folikel primer, (B) Folikel sekunder, (C) folikel tersier (Haematoxylin-Eosin, 400x) dan (D) folikel de Graff (Haematoxylin-Eosin, 100x).

Tabel 1. Rerata dan simpangan baku jumlah folikel primer, sekunder, tersier, dan de Graff ovarium mencit (Mus musculus) setelah diberi perlakuan IGF-I SKB

\begin{tabular}{ccccc}
\hline \multirow{2}{*}{ Perlakuan } & \multicolumn{4}{c}{ Jumlah Folikel $(\mathrm{x} \pm$ SD) } \\
\cline { 2 - 5 } & Folikel Primer & Folikel Sekunder & Folikel Tersier & Folikel de Graff \\
\hline K0 & $9,40^{\mathrm{a}} \pm 6,58$ & $6,20^{\mathrm{a}} \pm 3,11$ & $4,60^{\mathrm{a}} \pm 2,88$ & $3,40^{\mathrm{a}} \pm 2,79$ \\
P1 & $14,00^{\mathrm{ab}} \pm 2,82$ & $8,40^{\mathrm{a}} \pm 2,88$ & $8,40^{\mathrm{a}} \pm 2,88$ & $3,00^{\mathrm{a}} \pm 1,22$ \\
P2 & $23,80^{\mathrm{b}} \pm 7,19$ & $21,60^{\mathrm{b}} \pm 6,34$ & $8,60^{\mathrm{a}} \pm 4,27$ & $3,60^{\mathrm{a}} \pm 1,14$ \\
P3 & $20,40^{\mathrm{b}} \pm 4,87$ & $20,00^{\mathrm{b}} \pm 10,12$ & $11,0^{\mathrm{a}} \pm 4,41$ & $5,40^{\mathrm{a}} \pm 1,81$ \\
\hline
\end{tabular}

Keterangan : Superskrip yang berbeda pada satu kolom menunjukkan perbedaan yang nyata $(\mathrm{p}<0,05)$ $\mathrm{P} 1=$ diinjeksi $10 \mathrm{ng} / \mathrm{ml} I G F-I \mathrm{SKB}$ $\mathrm{P} 2=$ diinjeksi $20 \mathrm{ng} / \mathrm{ml} I G F-I \mathrm{SKB}$ $\mathrm{P} 3=$ diinjeksi $40 \mathrm{ng} / \mathrm{ml} I G F-I \mathrm{SKB}$

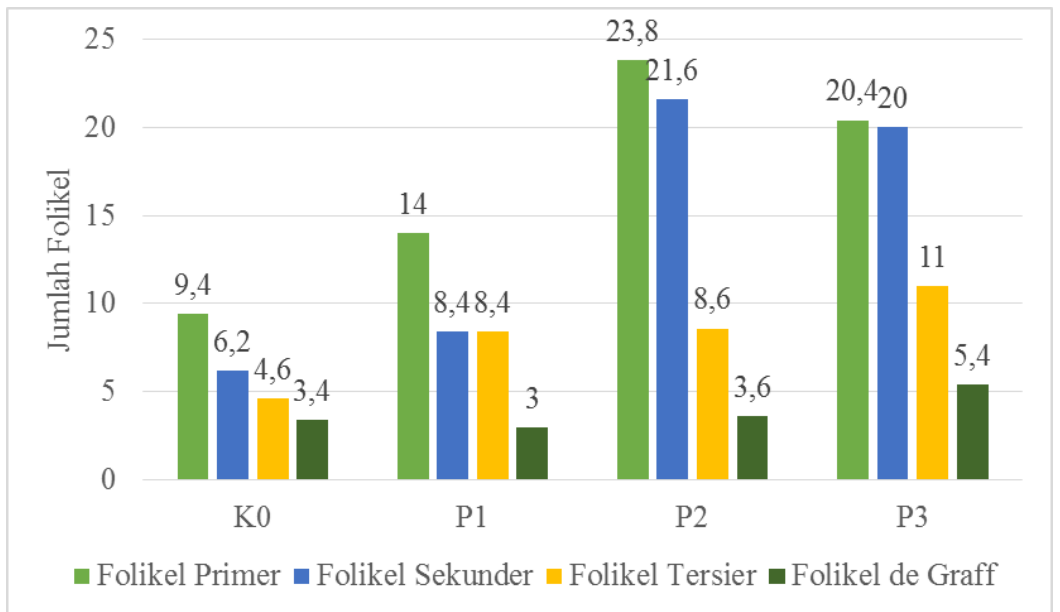

Gambar 2. Grafik rerata jumlah folikel primer, sekunder, tersier dan de Graff ovarium mencit (Mus musculus) setelah diberi perlakuan IGF-I SKB 
berfungsi menghasilkan hormon-hormon yang berguna bagi pertumbuhan dan perkembangan individu betina (Hoyer, 2004., Bhattacharya and Keating, 2012., Anderson and Hirshfield, 1992). Betina dilahirkan dengan jumlah folikel primordial yang terbatas yang nantinya akan habis dan tidak dapat bertambah lagi. Hal ini lah yang menyebabkan folikulogenesis disebut sebagai proses yang irreversibel (Edson et al. 2009., Hirshfield, 1991., dan Elvin and Matzuk, 1998). Folikulogenesis ovarium terdiri dari semua proses pertumbuhan folikel, diferensiasi, serta ovulasi dan lebih dari $99 \%$ folikel yang dihasilkan oleh ovarium akan berdegenerasi atau mengalami atresia. Pada mamalia, pertumbuhan folikel diatur oleh faktor endokrin seperti $F S H$ dan $L H$ serta fakor parakrin. Diantara faktor tersebut, suatu elemen yang disebut sistem Insulin-like Growth Factor (IGF) memainkan peran penting dalam memodulasi aktifitas gonadotropin dalam proliferasi dan diferensiasi sel-sel folikuler (Monget et al. 1996).

Berdasarkan hasil penelitian ini, pemberian Insulin-like Growth Factor-I (IGF-I) dari serum kuda crossbreed bunting dapat menambah jumlah folikel primer dan sekunder secara nyata $(\mathrm{P}<0,05)$ yang dibandingkan dengan kontrol. Jumlah folikel tersier dan de Graff dari mencit (Mus musculus) yang diinjeksi dengan Insulinlike Growth Factor-I (IGF-I) tidak berbeda nyata $(\mathrm{P}>0,05)$ dengan kelompok kontrol (K0). Dosis IGF-I $20 \mathrm{ng} / \mathrm{ml}$ dan $40 \mathrm{ng} / \mathrm{ml}$ dapat meningkatkan jumlah folikel primer dan sekunder secara signifikan $(\mathrm{P}<0,05)$ dibandingkan kelompok kontrol (K0). Hal ini membuktikan bahwa fungsi IGF-I pada sel-sel folikel yang dapat merangsang selsel reseptor tipe I pada sel-sel granulosa dan sel-sel teka (Giudice, 1992) dan ekspresi reseptor tersebut pada sel-sel granulosa ditingkatkan oleh adanya estrogen dan gonadotropin. Sedangkan ekspresi reseptor $I G F-I$ dapat meningkat pada folikel antral kecil (Wandji et al., 1992).

Dari hasil penelitian ini Insulin-like Growth Factor-I (IGF-I) dari serum kuda crossbreed bunting dapat meningkatkan jumlah folikel primer dan sekunder karena mencit yang digunakan belum memasuki pubertas. Hal ini sesuai dengan teori perkembangan folikel yang dikemukakan oleh
Partodihardjo (1992) dimana pada mencit umur pra pubertas seperti yang digunakan pada penelitian ini dalam ovarium mencit yang dominan adalah perkembangan folikel primer dan sekunder.

Terdapat pula teori yang menyatakan bahwa perkembangan folikel ovarium dibagi menjadi dua tahapan yaitu fase preantral dan antral. Fase preantral meliputi folikel primordial, folikel primer dan folikel sekunder. Fase preantral atau gonadotropinindependent phase ditandai dengan pertumbuhan dan diferensiasi oosit yang dipengaruhi oleh faktor-faktor pertumbuhan melalui sistem autokrin/parakrin, seperti Transforming Growth Factor $\beta$ (TGF- $\beta$ ) superfamily dan Insulin-like Growth Factor 1 (IGF-1). Fase antral atau fase gonadotropin-dependent ditandai dengan peningkatan pesat dari ukuran folikel itu. Fase antral meliputi folikel de graff. Fase antral diatur oleh Follicle Stimulating Hormone (FSH) dan Luteinizing Hormone ( $\mathrm{LH})$ serta faktor-faktor pertumbuhan lainnya. Faktor-faktor pertumbuhan ini akan merangsang proliferasi sel dan mempengaruhi aktivitas gonadotropin (Webb et al., 2004; Anwar, 2005; Gannon, 2013). Oleh karena itu, pada penelitian ini hanya folikel primer dan sekunder saja lah yang mengalami peningkatan jumlah yang signifikan sedangkan folikel tersier dan de Graff mengalami pertambahan ukuran.

Mekanisme kerja komplek protein $I G F-I$ dan $I G F B P-3$ pada folikel immature dan mature dijelaskan dalam Roche (1998) bahwa pada folikel immature, $L H$ akan merangsang sel teka untuk membentuk androgen dengan dibantu oleh $I G F-1$ dan aktivin yang berada di sel granulosa. $I G F-1$ akan berikatan IGFBP-3 kemudian dipecah dengan TIMP (Tissue Inhibitoring Metalo Proteinase) yang tinggi tetapi kemampuan memecahnya tidak terlalu besar sehingga IGF-1 dihasilkan tidak banyak. Androgen dibawa ke sel granulosa kemudian diubah menjadi estradiol melalui proses aromatisasi dan dirangsang oleh $I G F-I$ dan $F S H$.

Pada folikel mature, $L H$ akan merangsang sel teka untuk membentuk androgen dibantu oleh $I G F-I$ dan Inhibin yang berada di sel granulosa. IGFBP-3 akan dipecah oleh TIMP menghasilkan IGF-I dalam jumlah banyak. Androgen dibawa ke sel granulosa dan diubah menjadi estradiol 
melalui proses aromatisasi, dikontrol oleh enzim aromatase inhibitor yang dihasilkan oleh sel granulosa, kemudian dirangsang oleh IGF-I dan FSH sehingga sekresi estradiol meningkat (Roche, 1998). Hal ini lah yang membuat dalam pemeriksaan siklus estrus mencit yang digunakan yang mula-mula belum memasuki fase estrus akan memasuki fase estrus lebih cepat dan terus dipertahankan selama masa penyuntikan $I G F-I$.

Komplek protein IGF-I dan IGFBP-3 berpengaruh terhadap pembentukan $F S H$, dan hormon $F S H$ tersebut yang dihasilkan oleh hipofisa anterior akan berperan merangsang pertumbuhan folikel pada ovarium dan juga akan merangsang pembentukan reseptor $L H$ pada sel-sel folikel ovarium (Peters, 1985). Menurut Rochler (1993) penyuntikan kompleks protein $I G F-I$ dan IGFBP-3 pada fase diestrus dapat merangsang hipofisa anterior untuk menghasilkan $L H$ dan $F S H$ yang mensekresikan hormon estrogen dalam darah. Peningkatan sekresi estradiol oleh sel-sel folikel dominan saat ovulasi akan menyebabkan birahi dan merangsang banjir $L H$ serta pengeluaran ovum.

\section{Kesimpulan}

Pemberian Insulin-like Growth FactorI (IGF-I) dari serum kuda crossbreed bunting (SKB) dapat meningkatkan jumlah folikel primer dan sekunder. Dosis IGF-I SKB $20 \mathrm{ng} / \mathrm{ml}$ dan $40 \mathrm{ng} / \mathrm{ml}$ dapat meningkatkan jumlah folikel primer dan sekunder. Tidak ada dosis $I G F-I$ SKB yang dapat meningkatkan jumlah folikel tersier dan de Graff.

\section{Daftar Pustaka}

Anderson, L D. and Hirshfield, A N. 1992. An overview of follicular development in the ovary: from embryo to the fertilized ovum in vitro. $\mathrm{Md}$ Med J. 41: 614-620.

Anwar, R. 2005. Morfologi dan Fungsi Ovaium. Subbagian Fertilitas dan Endokrinologi Reproduksi Bagian Obstetri dan Ginekologi Fakultas Kedokteran Unpad.

Bhattacharya, P and Keating, A F. 2012. Impact of environmental exposures on ovarian function and role of xenobiotic metabolism during ovo- toxicity. Toxicol Appl Pharmacol; 261: 227-235.

BPS. 2015. Peternakan. Badan Pusat Statistik Nasional.

Direktorat Jendral Peternakan dan Kesehatan Hewan. 2015. Statistik Peternakan dan Kesehatan Hewan 2015. Kementerian Pertanian.

Echternkamp, SE., Spicer, LJ., Gregory, KE., Canning, SF., Hammond, JM. 1990. Concentrations of insulinlike growth factor-I in blood and ovarian follicular fluid of cattle selected for twins. Biol Reprod. 43: 8-14.

Edson, M. A., Nagaraja, A. K., Matzuk, M. M. 2009. The mammalian ovary from genesis to revelation. Endocr Rev. 30: 624-712.

Elvin, J A., Matzuk, M. M. 1998. Mouse models of ovarian failure. Rev Reprod. 3:183-195.

Gannon, A.M. 2013. Expossure To Cigarette Smoke And Its Impact On The Ovarian Follicle Population Mechanisms Of Follicle Loss. Canada: McMaster University.

Giudice, L.C. 1992. Insulin-like Growth Factor and Ovarian Follicular Development. Endocrine Reviews. 13: 641-669.

Gougeon, A. 1996. Regulation of ovarian follicular development in primates: facts and hypotheses. Endocr Rev. 17: 121-55.

Griffin, J., Benjamin, R., Emery, B. R., Huang, I., Peterson, C. M., Carrell, D. T. 2006. Comparative analysis of follicle morphology and oocyte diameter in four mammalian species (mouse, hamster, pig, and human). J Exp Clin Assist Reprod. $3: 2$.

Hirshfield, A N. 1991 Development of follicles in the mammalian ovary. Int Rev Cytol. 124: 43-101.

Hoyer, P B. 2004. Can the clock be turned back on ovarian aging? Sci Aging Knowl Environ 2004. p:11.

Ismudiono, Srianto, P., Anwar, H., Madyawati, S.P., Samik, A., dan Safitri, E. 2010. Buku Ajar Fisiologi Reproduksi Pada Ternak. Airlangga University Press. Surabaya. 
Kementerian Pertanian. 2016. Peraturan Menteri Pertanian (Permentan) no. 48 tahun 2016 tentang Upaya Khusus Percepatan Peningkatan Populasi Sapi dan Kerbau Bunting. Kementerian Pertanian Republik Indonesia.

Kusriningrum, R.S. 2011. Perancangan Percobaan. Airlangga University Press. Surabaya. Hal : 165-212.

Magalhaes-Padilhaa, D.M., Duarte, A.B.G., Araujo, V.R., Saraiva, M.V.A., Almeida, A.P., Rodrigues, G.Q., Matos, M.H.T., Campello, C.C., Silva, J.R. and M.O. Gastal. 2012. Steady-state Level of Insulin-Like Growth Factor-I (IGF-I) Receptor mRNA and The Effect of IGF-I on the In Vitro Culture of Caprine Preantral Follicles. Theriogenology 77: 206-213.

Monget, P., Besnard, N., Huet, C., Pisselet, C., Monniaux, D. 1996. Insulin-like growth factor-binding proteins and ovarian folliculogenesis. Horm Res 45: 211-217.

Neira, J.A., Tainturier, D., Pen, M.A. and J. Martal. 2010. Effect of the Association of IGF- I, IGF-II, bFGF, TGF-b1, GM-CSF, and LIF on the Development of Bovine Embryos Produced In Vitro. Theriogenology . 73: 595-604.

Nursyah, D.A. 2012. Gambaran Siklus Estrus Tikus Putih (Rattus norvegicus) Ovariektomi Yang Diberi Tepung Daging Teripang (Holothuria scabra) [Skripsi]. Fakultas Kedokteran Hewan. Institut Pertanian Bogor. Bogor.

Oberlender, G., Murgas, L.D.S., Zangeronimo, M.G., da Silva, A.C., Menezes, T.A., Pontelo, T.P. and L.A. Vieira. 2013. Role of Insulin-Like Growth Factor-I and Follicular Fluid from Ovarian Follicles with Different Diameters on Porcine Oocyte Maturation and Fertilization In Vitro. Theriogenology. 80: 319-327.

Palermo, R. 2007. Differential Actions of FSH and LH During Folliculo- genesis. Reproductive BioMedicine 15(3): 326-337.

Partodiharjo, S. 1992. Ilmu Reproduksi Hewan. Ed. Ke-3. Jakarta: Mutiara Sumber Widya.

Pedersen T, and Peters H. 1968. Proposal For A Classification of Oocytes and Follicles in The Mouse Ovary. J Reprod Fertil. 17: 555-557.

Peters, A. R. 1985. Hormonal Control of Bovine Oestrous Cycle 1. The Natural Cycle. Br. Vet. J. Reprod. Fertil. 14: 546-573

Roche, J. F. 1998. Controls of Folliculogenesis. J Theriology. 49: 457-467

Rochler, M. M. 1993. Insulin-like Growth Factor Binding Protein, Vitamins and Hormone. J. Reprod. Fertil. 47: $1-114$

Silva, J. R. V., Figueiredo, J. R., van den Hurk, R. 2009. Involvement of Growth Hormone (GH) and Insulin-Like Growth Hormone (IGF) system in ovarian folliculogenesis. Theriogenology 71: 1193-1208.

Singhal, S., Prasad, S., Singh, B., Prasad, J.K. and H.P. Gupta. 2009. Effect of Including Growth Factors and Antioxidants in Maturation Medium Used for In Vitro Culture of Buffalo Oocytes Recovered In Vivo. Anim Reprod Sci. 113:44- 50.

Ulum, F. M. dan Purwanta, B. 2015. Manual : Manajemen Kesehatan Reproduksi Ternak Sapi. Lembaga Penelitian dan Pengabdian Kepada Masyarakat. Institut Pertanian Bogor. Bogor.

Wandji, S.A., Teresa, L.W., Jennifer, C., Steven, W.L. and J.M. Hammond. 1998. Expression of Mouse Ovarian Insulin-like Growth Factor System Companent During Follicle Development and Atresia. Endocrinology. 134: 5205-5214.

Webb, R., Garnsworthy, PC., Gong, JG., and Armstrong, DG. 2004. Control of Follicular Growth: Local Interaction and Nutritional Influence. Journal of Animal Science. 82 : E63-E74. 